\title{
Front Matter: Volume 11829
}

, "Front Matter: Volume 11829," Proc. SPIE 11829, Earth Observing Systems XXVI, 1182901 (9 September 2021); doi: 10.1117/12.2606283

SPIE Event: SPIE Optical Engineering + Applications, 2021, San Diego, California, SPIE. United States 


\section{PROCEEDINGS OF SPIE}

\section{Earth Observing Systems XXVI}

James J. Butler

Xiaoxiong (Jack) Xiong

Xingfa Gu

Editors

1-5 August 2021

San Diego, California, United States

Sponsored and Published by

SPIE 
The papers in this volume were part of the technical conference cited on the cover and title page. Papers were selected and subject to review by the editors and conference program committee. Some conference presentations may not be available for publication. Additional papers and presentation recordings may be available online in the SPIE Digital Library at SPIEDigitallibrary.org.

The papers reflect the work and thoughts of the authors and are published herein as submitted. The publisher is not responsible for the validity of the information or for any outcomes resulting from reliance thereon.

Please use the following format to cite material from these proceedings:

Author(s), "Title of Paper," in Earth Observing Systems XXVI, edited by James J. Butler, Xiaoxiong (Jack) Xiong, Xingfa Gu, Proc. of SPIE 11829, Seven-digit Article CID Number (DD/MM/YYYY); (DOI URL).

ISSN: 0277-786X

ISSN: 1996-756X (electronic)

ISBN: 9781510644960

ISBN: 9781510644977 (electronic)

Published by

SPIE

P.O. Box 10, Bellingham, Washington 98227-0010 USA

Telephone +1 3606763290 (Pacific Time)

SPIE.org

Copyright @ 2021 Society of Photo-Optical Instrumentation Engineers (SPIE).

Copying of material in this book for internal or personal use, or for the internal or personal use of specific clients, beyond the fair use provisions granted by the U.S. Copyright Law is authorized by SPIE subject to payment of fees. To obtain permission to use and share articles in this volume, visit Copyright Clearance Center at copyright.com. Other copying for republication, resale, advertising or promotion, or any form of systematic or multiple reproduction of any material in this book is prohibited except with permission in writing from the publisher.

Printed in the United States of America by Curran Associates, Inc., under license from SPIE.

Publication of record for individual papers is online in the SPIE Digital Library.

\section{SP|E. DIGITAL}

Paper Numbering: A unique citation identifier (CID) number is assigned to each article in the Proceedings of SPIE at the time of publication. Utilization of CIDs allows articles to be fully citable as soon as they are published online, and connects the same identifier to all online and print versions of the publication. SPIE uses a seven-digit CID article numbering system structured as follows:

- The first five digits correspond to the SPIE volume number.

- The last two digits indicate publication order within the volume using a Base 36 numbering system employing both numerals and letters. These two-number sets start with 00, 01, 02, 03, 04, 05, 06, 07, 08, 09, 0A, OB ... 0Z, followed by 10-1Z, 20-2Z, etc. The CID Number appears on each page of the manuscript. 


\section{Contents}

REMOTE SENSING DATA ALGORITHMS, PROCESSING, AND ANALYSIS

$1182904 \quad$ Improving the CERES SYN cloud and flux products by identifying GOES-17 scan anomalies using a convolutional neural network [1 1829-13]

$1182905 \quad$ Using remote sensing imagery to study urban heat island and heat waves [11829-14]

1182906 Characterizing water and non-water sites from cropland in eastern South Dakota using Sentenel-1 SAR images [1 1829-16]

1182907 Remote monitoring capabilities for arctic water surface and ice covers [11829-17]

1182908 About mathematical models of "spotting" in the problems of remote monitoring of aquatic ecosystems [11829-18]

\section{INSTRUMENT INTERCOMPARISONS}

1182909 Comparison of AIRS and CrIS SNPP and JPSS radiometry between 2018 and 2021 [11829-19]

11829 OA Learning spatial response functions from large multi-sensor AIRS and MODIS datasets [1 1829-20]

POSTLAUNCH INSTRUMENT VALIDATION \& VICARIOUS CALIBRATION

11829 OC Post-launch radiometric calibration of the GOES-16 and GOES-17 advanced baseline imager [11829-36]

11829 OD Additional characterization of Dome-C to improve its use as an invariant visible calibration target [1 1829-34]

11829 OE S-NPP and NOAA-20 VIIRS thermal emissive bands calibration stability assessments using an in situ ocean target [11829-37]

\section{LANDSAT -8 \& 9}

11829 OF Landsat-8 TIRS radiometric calibration status [1 1829-22]

11829 OG Radiometric performance of Landsat 8 Collection 2 products [1 1829-23] 
$11829 \mathrm{OH} \quad$ Comparing geometric differences between Landsat Collection 1 to Collection 2 level-1 products [11829-24]

1182901 Preliminary assessment of the geometric improvements to the Landsat Collection-2 archive [11829-25]

11829 0J Landsat 9: ready for launch [11829-26]

11829 OK Landsat 9 Operational Land Imager2 (OLI2) enhanced on-orbit linearity characterization [11829-27]

PRELAUNCH INSTRUMENT CALIBRATION \& CHARACTERIZATION I

11829 OL Prelaunch characterization and performance of JPSS-3 VIIRS reflective solar bands [1 1829-1]

11829 OM JPSS-3 VIIRS day-night band pre-launch radiometric characterization [1 1829-2]

11829 ON JPSS-3 VIIRS response versus scan angle characterization and performance [11829-3]

1182900 JPSS-3 VIIRS prelaunch geometric calibration and characterization status [1 1829-4]

PRELAUNCH INSTRUMENT CALIBRATION \& CHARACTERIZATION II

$118290 Q \quad$ PACE OCI pre-launch ETU spectral characterization and performance [1 1829-7]

11829 OR PACE Ocean Color Instrument polarization testing and results [11829-8]

11829 OS Progressive TDI measurements with the PACE OCI ETU [1 1829-9]

11829 OT Multi-Angle Imager for Aerosols (MAIA) spectral and radiometric calibration [11829-10]

11829 OU Geometric calibration of the Multi-Angle Imager for Aerosols (MAIA) [1 1829-1 1]

POSTLAUNCH INSTRUMENT OPERATION, CALIBRATION, \& CHARACTERIZATION

11829 OV Restoration of degraded Suomi-NPP VIIRS DNB nighttime imagery induced by electronic bias change [11829-28]

11829 OW The effects of NOAA-20 VIIRS Solar Diffuser Stability Monitor (SDSM) Relative Spectral Response (RSR) on the Solar Diffuser (SD) degradation estimations [1 1829-29]

11829 OX NOAA 20 VIIRS Solar Diffuser Stability Monitor (SDSM) sun transmittance function update from Yaw maneuver and 3 year on-orbit SDSM data [1 1829-30]

iv 
11829 OY Ground control points refresh for MODIS and VIIRS geolocation monitoring [11829-31]

$11829 \mathrm{OZ}$ MODIS reflective solar band calibration improvements using pseudo-invariant desert targets [11829-32]

1182910 Tracking on-orbit changes in response versus scan angle for MODIS reflective solar bands using Dome C [1 1829-33]

\section{POSTER SESSION}

1182911 JPSS-3 VIIRS pre-launch thermal emissive band calibration [1 1829-47]

1182912 S-NPP/NOAA-20 VIIRS reflective solar bands on-orbit calibration bias investigation [1 1829-48]

1182914 Ship target detection method for SAR image of FNLM filtering combined with faster R-CNN [11829-39]

1182915 Building extraction algorithm based on improved adaptive $\mathrm{MBI}$ index in remote sensing image [11829-40]

1182916 Research on fusion of SAR image and multispectral image using texture feature information [11829-41]

1182917 Research on farmland boundary extraction based on deep learning and edge detection operator for GF-2 data [1 1829-42]

1182918 Performance assessment of the NOAA-20 VIIRS RSB using deep convective clouds [11829-43]

1182919 S-NPP and NOAA-20 VIIRS thermal emissive bands diurnal F-factor oscillations impacts on Earth view retrievals [1 1829-44]

11829 1A Impact of mirror-side correlated noise on radiometric calibration of MODIS thermal emissive bands [1 1829-45]

11829 1B Intercalibration of the reflective solar bands of MODIS and MISR instruments on the Terra platform [1 1829-46]

11829 1C Research of the impact of solid domestic and industrial waste on the snow and ice coverage of mountain territories of the Northern Caucasus using remote sensing technology [1 1829-50] 
Proc. of SPIE Vol. 11829 1182901-6

\section{Downloaded From: https://www.spiedigitallibrary.org/conference-proceedings-of-spie on 26 Apr 2023
Terms of Use: https://www.spiedigitallibrary.org/terms-of-use}

